\title{
PENGARUH MINAT DAN KEBIASAAN MEMBACA SISWA TERHADAP HASIL BELAJAR GEOGRAFI SMA
}

\author{
Onik Farida Ni'matullah \\ Universitas Kanjuruhan Malang \\ E-mail: onikfarida@yahoo.com
}

\begin{abstract}
Abstrak
Membaca adalah salah satu cara untuk mendapatkan informasi dan pengetahuan. Seseorang akan lebih kaya informasi dan wacana apabila ia memiliki minat dan kebiasaan membaca yang baik. Begitu pula pada seorang pelajar atau siswa. Intensitas dan kualitas mereka dalam membaca bisa menjadi penyebab kesuksesan saat pembelajaran di sekolah. Minat membaca yang ada pada diri siswa sangat berkaitan dengan kebiasaan mereka dalam kehidupan sehari-hari. Misalnya pada mata pelajaran geografi yang banyak memuat fakta dan konsep sehingga sangat memerlukan aktivitas membaca untuk memahaminya. Prestasi yang maksimal pada mata pelajaran geografi bergantung pada tinggi rendahnya minat dan kebiasaan mereka dalam membaca buku atau tulisan ilmiah yang berkaitan dengan materi pelajaran. Oleh karena itu guru di sekolah diharapkan dapat memilih strategi pembelajaran yang dapat memacu motivasi agar siswa tertarik dengan membaca sehingga akan mendapatkan pencapaian hasil belajar yang optimal.
\end{abstract}

Kata Kunci: Minat membaca, kebiasaan membaca, hasil belajar

\section{PENDAHULUAN}

Harjasujana (1988) mengungkapkan bahwa minat yang tinggi terhadap suatu topik akan memberikan energi mental tambahan yang diperlukan dalam upaya menyarikan informasi dari suatu teks, sehingga minat membaca memegang peranan yang penting dalam menunjang keberhasilan membaca. Minat yang tinggi dalam membaca merupakan salah satu faktor yang turut menentukan keberhasilan siswa (Singh, 2011). Begitu pula hasil penelitian yang dilakukan oleh Ogbodo (2010), Bhan dan Gupta (2010) juga menjelaskan minat membaca memberikan peran terhadap keberhasilan dalam belajar. Oleh sebab itu, pengembangan minat dan kebiasaan membaca di sekolah hendaknya menjadi dasar untuk pengembangan intelektual. Guru harus mampu menyadarkan dengan memberikan motivasi dan memberi contoh para siswa agar selalu membina dan meningkatkan kualitas diri melalui kegiatan membaca buku-buku yang berkaitan dengan bidang studi.

Kesuksesan seseorang tergantung pada prestasi yang pernah ia capai. Sistem yang ada mengharuskan masing-masing individu untuk menunjukkan karakternya untuk bertahan. Sistem pendidikan di era modern begitu banyak mengalami perkembangan. Hasil akhir dalam suatu pembelajaran bukanlah kunci dari sistem pendidikan yang ada. Namun demikian, pada suatu proses yang baik, sangat mustahil akan menuai hasil/pencapaian akhir yang sebaliknya. Begitu pula, pada siswa yang sedang menempuh pendidikan. Proses yang baik dalam pembelajaran niscaya akan memperoleh prestasi yang optimal.

Banyak faktor yang dapat menentukan kunci kesuksesan siswa dalam proses pembelajaran. Salah satunya yaitu minat dan kebiasaan membaca. Hal tersebut dikarenakan tinggi rendahnya minat dan kebiasaan membaca sangat berpengaruh 
pada kesuksesan siswa meraih hasil maksimal dalam pembelajaran (Wahyuningtyas, 2012). Keberadaan motivasi dalam diri siswa yang berupa minat membaca, akan menambah energi mereka akan hausnya pengetahuan. Adanya kemauan yang tinggi untuk membaca mendorong siswa untuk terus berproses menjadi lebih baik. Selanjutnya, dengan minat membaca yang dimiliki siswa, maka lambat laun akan terbentuk suatu kebiasaan membaca dalam dirinya. Kebiasaan tersebut merupakan bentuk manifestasi dari minat membaca yang rutin, teratur, kontinyu, dan berkesinambungan. Oleh karena itu dapat dikatakan bahwa minat dan kebiasaan membaca memiliki keterkaitan yang sangat erat.

Terbentuknya minat dan kebiasaan membaca seseorang membutuhkan waktu yang lama dan proses yang sangat panjang. Sebagaimana dikemukakan Tampubolon dalam Nurhayatin (1997):

"minat dan kebiasaan membaca yang baik sebagai bagian dari budaya tulisan tidak mungkin dimiliki dalam waktu yang singkat. Pengembangannya memakan waktu yang relatif lama. Oleh karena itu pembinaan minat baca harus dilakukan sejak usia dini, sehingga pada usia dewasa telah memiliki kebiasaan dan kemampuan membaca yang baik."

Pendapat tersebut menyiratkan bahwa minat dan kebiasaan membaca tidak terbentuk secara instan. Proses minat yang perlahan menjadi suatu kebiasaan membutuhkan proses yang panjang. Oleh sebab itu pembinaan dini pada siswa sangat diperlukan utuk menumbuhkembangkan minat dan kebiasaan membaca mereka. Terutama pada mata pelajaran yang banyak mengandung fakta dan konsep seperti geografi.

Geografi merupakan bidang studi wajib yang dipelajari siswa di sekolah. Bidang kajiannya diantaranya meliputi manusia, bumi (lingkungan), dan hubungan timbal balik antara keduanya. Pada bidang studi geografi, hubungan manusia dan lingkungan digambarkan sebagai sistem keruangan/spasial system. Bidang studi geografi terdiri dari fakta, konsep, generalisasi, dan subtansi (isi) seperti: teori, hukum, dalil, dan prinsip (Astina, 2005). Oleh sebab itu dalam pembelajaran geografi sangat dibutuhkan aktivitas membaca sebagai salah satu cara untuk mendapatkan pengetahuan.

Pada kenyataannya, kondisi minat dan kebiasaan membaca siswa tidaklah seperti yang banyak orang bayangkan. Status pelajar bukanlah jaminan mereka selalu giat membaca buku. Data survey penulis pada Februari 2015 mencatat bahwa kebanyakan minat dan kebiasaan siswa untuk membaca buku sangat rendah bila dibandingkan dengan kegiatan lainnya seperti mengobrol, bemain game atau pun bermedsos ria di dunia maya. Temuan penelitian Wahyuningtyas (2012) juga membuktikan bahwa keadaan rata-rata kondisi minat dan kebiasaan membaca siswa rendah. Terlebih penelitian tersebut dilakukan pada mahasiswa yang notabene jurusan geografi. Sebagian besar hasil penelitian juga menyatakan bahwa terdapat hubungan antara minat dan kebiasaan membaca siswa terhadap variabel yang ditentukan peneliti, misalnya hasil dan prestasi belajar. Kesimpulannya, terdapat dampak yang signifikan bila kebiasaan dan minat membaca siswa dihubungkan dengan hasil maupun prestasi belajar.

Tidak jauh berbeda dengan penelitian sebelumnya (Wahyuningtyas, 2012) siswa Sekolah Menengah Atas (SMA) juga memiliki minat dan kebiasaan membaca yang rendah. Mereka juga cenderung lebih tertarik membaca buku 
lain seperti komik, tabloid bola, dan koran daripada membaca tulisan ilmiah yang berkaitan dengan materi pelajaran. Sebagian dari mereka bahkan terindikasi selalu membaca buku pelajaran apabila akan ulangan atau ada tugas saja. Hal ini menunjukkan bahwa siswa hanya berorientasi terhadap hasil ujian. Proses pembelajaran yang menuntut siswa untuk mencari dan mengolah informasi dan pengetahuan seakan tidak berpengaruh terhadap hasil ujiannya. Siswa tersebut hanya membaca materi pelajaran dari buku agar bisa menjawab soal yang diberikan dalam ujian. Buku teks yang dibawa siswa sebagian besar kurang dimanfaatkan. Buku tersebut lebih banyak berfungsi sebagai pendukung untuk mengerjakan tugas rumah, menyiapkan ujian tengah semester dan akhir semester.

\section{PEMBAHASAN}

\section{Pengaruh Minat Membaca terhadap Hasil Belajar Geografi}

Wigfield dan Guthrie (1997) mengatakan bahwa "students who have low reading interests will also be low in learning achievement, conversely students who have high reading interest will also be high in learning achievement". Secara umum siswa yang memiliki minat membaca rendah juga akan berprestasi rendah, sebaliknya siswa yang memiliki minat membaca tinggi maka akan berprestasi tinggi. Sejalan dengan itu, Rahim (2008) menyatakan bahwa minat baca adalah keinginan yang kuat disertai usaha-usaha siswa untuk membaca. Usaha siswa untuk membaca merupakan suatu proses yang di dalamnya terkandung bagaimana strategi untuk membaca dalam rangka mengambil informasi dari bahan bacaan tertentu. Pendapat tersebut menjelaskan bahwa usaha siswa untuk membaca dapat dikategorikan dalam self-regulated learning dalam mengatur belajarnya sendiri (dengan membaca), sehingga hasil belajar yang didapat akan optimal. Dalam konteks ini adalah memperoleh pencapaian nilai/hasil belajar yang optimal khususnya pada mata pelajaran geografi.

Lebih lanjut mengenai minat membaca, Listariono (2009) menjelaskan bahwa siswa yang memiliki minat membaca dalam dirinya akan memiliki gairah atau kecenderungan untuk melihat serta memahami isi dari apa yang ditulis, baik dengan melafalkan atau mengeja apa yang ditulis atau hanya dalam hati, serta disertai dengan perasaan senang karena merasa ada kepentingan terhadap hal tersebut. Oleh karena itu, minat membaca sangat penting bagi perkembangan seseorang khususnya siswa. Bashir dan Mattoo (2012) menambahkan minat membaca membantu siswa selalu baik dalam akademik pada setiap situasi. Selain itu siswa memperoleh makna dan pengetahuan yang diperlukan. Penelitian yang dilakukan oleh Ogbodo (2010), Bhan dan Gupta (2010), dan Singh (2011) juga menjelaskan minat membaca memberikan peran terhadap keberhasilan dalam belajar. Pada hakekatnya dalam teori tersebut tersirat bahwa minat membaca yang ada pada seorang siswa dapat berperan sebagai sumber pendorong bagi siswa untuk melakukan suatu kegiatan membaca. Apabila kegiatan tersebut dapat berlangsung secara terus menerus niscaya akan memperoleh hasil belajar yang lebih baik. Minat membaca dalam intensitas tinggi akan menghasilkan kebiasaan dan kemampuan membaca yang baik, dan pada akhirnya akan memainkan peranan penting bagi pelajar yang sukses. 
Dalam minat membaca terkandung unsur perhatian, kemauan, dorongan, dan rasa senang yang timbul dari dalam diri maupun dari pengaruh orang lain (Ginting, 2005). Pendapat tersebut menunjukkan bahwa siswa melakukan usaha (kemauan) untuk membaca sebagai strategi untuk memahami suatu informasi dari buku yang dibaca. Maka dari itu jika siswa yang berminat pada suatu objek, pasti perhatiannya akan terpusat pada objek tersebut. Perhatian itulah yang kemudian akan mendorong siswa rajin belajar untuk mencapai apa yang diinginkan. Begitu pun dalam aktivitas membaca, jika siswa berminat terhadap membaca, bisa dipastikan perhatiannya akan terpusat pada bahan bacaan (buku) yang dibaca tersebut. Minat inilah pada akhirnya yang akan timbul dan terus tumbuh pada diri siswa apabila ia dapat merasakan kepuasan dan manfaatnya dalam aktivitas kehidupan sehari-hari.

Minat merupakan salah satu faktor penting untuk meraih kesuksesan. Keberadaan minat akan dapat mendorong seseorang untuk melakukan sesuatu (Gie, 1998). Gie juga menyatakan dari hasil penelitian di Amerika Serikat tercatat bahwa penyebab utama pelajar mengalami kegagalan dikarenakan kurangnya minat. Pendapat tersebut menyiratkan bahwa faktor internal seperti minat merupakan modal dasar bagi siswa untuk meraih kesuksesan. Apabila siswa memiliki minat terhadap membaca, maka ia akan berhubungan secara aktif dengan kegiatan membaca yang menarik perhatiannya itu. Hal ini jika terus berkembang dengan baik maka akan membuahkan hasil yang memuaskan yaitu perolehan pengetahuan dari bacaan akan meningkat, hasil belajarnya menjadi optimal dan sekaligus memperbesar minatnya terhadap kegiatan membaca tersebut.

Melihat teori dan pendapat di atas dapat dikatakan bahwa membaca adalah sumber inspirasi dan pengetahuan. Membaca merupakan salah satu aktivitas belajar yang efektif untuk mendapatkan ilmu dan pengetahuan. Secara praktis siswa dapat memperoleh pengetahuan dengan cepat dan efisien karena tinggal memilih buku yang akan dibacanya. Selain itu, tinggi dan rendahnya minat membaca pada siswa mempunyai hubungan yang erat dengan hasil belajar. Adanya motivasi intrinsik yang berupa minat sangat dibutuhkan untuk mencapai keberhasilan akademik. Di samping minat membaca, faktor lain yang berhubungan dengan pencapaian hasil belajar diantaranya yaitu kepribadian dan kemampuan kognitif.

Berdasarkan konsep dan teori di atas maka diharapkan guru di sekolah dapat memilih strategi pembelajaran yang dapat memacu motivasi agar siswa tertarik dengan membaca dan memperkuat minat dalam membaca, sehingga siswa akan mendapatkan pencapaian hasil belajar yang optimal. Terlebih pada mata pelajaran geografi yang banyak mengandung, konsep, generalisasi, dan subtansi, seperti: teori, hukum, dalil, dan prinsip, dimana dalam pembelajarannya sangat membutuhkan kegiatan membaca sebagai salah satu cara untuk memperoleh informasi. Jadi, dalam rangka mengembangkan minat membaca tersebut guru harus mampu menyadarkan dan memberi contoh pada siswa agar selalu membina dan meningkatkan kualitas diri melalui kegiatan membaca buku terutama yang berkaitan dengan bidang studi. 


\section{Pengaruh Kebiasaan Membaca terhadap Hasil Belajar Geografi}

Owusu-Acheaw \& Larson (2014) dalam penelitiannya menyimpulkan bahwa kebiasaan membaca berpengaruh pada peningkatan akademik. Mereka juga menyatakan ada hubungan secara langsung antara kebiasaan membaca dengan prestasi akademik. Hasil belajar yang optimal merupakan salah satu perwujudan dari prestasi tersebut. Kebiasaan membaca yang dimaksud adalah sikap siswa yang selalu tertuju pada bahan bacaan dan frekuensi kehadirannya di perpustakaan untuk membaca buku. Selanjutnya, dijelaskan pula bahwa salah satu kendala utama untuk membudayakan kebiasaan membaca adalah rasa malas yang ada dalam diri siswa.

Hal senada juga dikemukakan oleh Gie (1998) bahwa "kebiasaan membaca yang baik akan membantu siswa dalam menguasai pelajarannya, sehingga mampu mencapai kemajuan studi, dan akhirnya sukses di sekolah". Pendapat tersebut sangat jelas menyatakan bahwa kebiasaan membaca yang baik berarti membiasakan diri dengan melakukan kegiatan membaca yang tepat, teratur dan disiplin untuk mencapai hasil belajar yang maksimal. Kebiasaan yang ada pada siswa cenderung akan menguasai tindakan dan perilakunya saat mereka melakukan suatu aktivitas. Pada umumnya masing-masing individu akan bertindak berdasarkan force of habit, yaitu semacam kekuatan yang memaksa untuk melakukan tindakan karena sudah terbiasa. Hal ini dikarenakan dalam kebiasaan terdapat motivasi yang kuat. Motivasi inilah yang nantinya berperan sebagai motor penggerak untuk seseorang bertindak. Selain itu sesuai dengan law of effect dalam kegiatan, perbuatan yang menimbulkan kesenangan akan cenderung untuk diulang. Oleh karena itu, tindakan berdasarkan kebiasaan bersifat mengukuhkan (Wahyuningtyas, 2012).

Dalam aktivitas membaca sebenarnya juga terdapat seni. James W. dalam Wahyuningtyas (2012) menyiratkan pada bukunya bahwa membaca bukanlah suatu kegiatan yang sederhana seperti apa yang diperkirakan banyak orang. Membaca merupakan proses memaknai yang melibatkan interaksi antara pembaca dan teks. Maka dari itu, untuk dapat menikmati seni dari membaca perlu keterampilan atau teknik-teknik yang tepat guna mencapai tujuan yang diharapkan. Teknik-teknik tersebut antara lain yaitu teknik baca-pilih (selecting), baca-lompat (skipping), baca-layap (skimming), baca-tatap (scanning). Jika siswa sebagai pembaca dapat menerapkan teknik tersebut, niscaya akan menjadi seseorang yang lebih aktif dalam belajar dan mencapai hasil belajar yang maksimal. Selain itu untuk menguasai teknik keterampilan tersebut dibutuhkan latihan secara teratur dan kontinyu, oleh karena itu perlu upaya untuk membiasakan diri membaca.

Kebiasaan sangat erat hubungannya dengan waktu. Sebagaimana pepatah orang barat, "time is money" atau waktu adalah uang. Kebanyakan siswa yang tidak memiliki kebiasaan membaca yang baik maka yang akan menjadi alasan utama mereka adalah kesulitan dalam mengatur waktu. Padahal kebiasaan membaca sendiri berawal dari niat siswa bagaimana dalam mempersiapkan waktu luangnya sebagai modal belajar secara bertahap agar di akhir semester tidak terlalu banyak bahan bacaan yang akan dibaca sebagai bahan ujian. Namun yang terjadi adalah siswa meremehkan kebiasaan membaca tersebut dan 
sebagian besar memanfaatkan waktu membacanya ketika sudah terdesak. Ibarat pertandingan sepak bola, siswa cenderung lebih memanfaatkan "injury time" atau menit-menit terakhir menjelang ujian untuk membaca. Akibatnya hasilnya pun kurang maksimal.

James W. dalam Wahyuningtyas (2012) mengatakan bahwa "waktu membaca erat kaitannya dengan efisiensi". Dari pendapat tersebut tersirat jelas bahwa waktu merupakan hal yang sangat penting untuk diperhatikan karena menentukan berhasil tidaknya seseorang dalam berbuat sesuatu. Pada dasarnya input waktu bagi semua orang adalah sama. Namun, bisa dilihat pencapaian setiap orang berbeda-beda antara satu dengan yang lainnya. Hal ini disebabkan oleh efisiensi yang dimiliki setiap orang dalam memanfaatkan waktu berbeda. Begitu halnya dalam membaca, jika seseorang tersebut mampu mengelola waktu belajarnya dengan baik, artinya mempunyai efisiensi waktu maka dia akan lebih unggul dibandingkan dengan seseorang yang tidak memiliki efisiensi waktu.

Pernyataan di atas menyimpulkan bahwa membiasakan diri meluangkan waktu untuk membaca akan memberikan pengaruh yang sangat besar bagi kehidupan. Seseorang tidak akan meraih kesuksesan tanpa ada upaya. Dalam hal ini terutama bagi siswa, kesuksesan mereka dalam meraih hasil belajar yang optimal bergantung pada managemen waktunya untuk membaca. Tidak akan pernah ada orang pintar atau cerdas sekalipun yang meraih kesuksesan tanpa harus membaca, karena dari bacaanlah seseorang dapat menyerap ilmu pengetahuan dan segala informasi.
Maka dari itu guru dan sekolah harus saling bersinergi dalam mengupayakan budaya kebiasaan membaca di kalangan siswa. Guru menentukan dan mengarahkan siswa untuk memilih bahan bacaan yang sesuai dengan kebutuhan mereka. Sedangkan sekolah mengupayakan untuk menyediakan bahan bacaan atau buku-buku tersebut dan mengatur pelayanannya secara khusus sehingga peluang setiap siswa untuk membacanya dapat terjamin. Di samping itu, sekolah juga harus menyediakan tempat yang nyaman dan representatif untuk membaca misalnya perpustakaaan yang ideal serta guru juga mengajarkan pada siswa bagaimana teknik dan cara membaca yang baik.

\section{Pengaruh Minat dan Kebiasaan Membaca siswa terhadap Hasil Belajar Geografi SMA}

Drummond dan Stoddard dalam Wahyuningtyas (2012) menyatakan bahwa beberapa faktor yang berkaitan dengan hasil belajar diantaranya yaitu minat dan kebiasaan membaca. Kedua faktor tersebut memegang peranan penting bagi siswa untuk dapat melakukan usaha belajar dengan baik. Apabila siswa telah memiliki kedua hal tersebut yaitu minat dan kebiasaan membaca, maka ia telah memiliki niat yang tinggi untuk membaca baik dalam rangka menyelesaikan tugas-tugas maupun menunjang keberhasilan belajarnya.

Pada dasarnya setiap siswa memiliki tingkatan minat untuk tertarik pada bahan bacaan baik saat mereka berada di rumah, sekolah, atau pun perpustakaan. Keberadaan minat tersebut sangat penting untuk dikembangkan. Maka dari itu perlu dukungan dari lingkungan agar mereka bisa membudayakan dan mengarahkan motivasi keingintahuannya 
ke arah yang lebih baik. Dengan begitu diharapkan membaca akan menjadi sumber inspirasi dan pengetahuan yang pada akhirnya akan membuat siswa lebih kreatif dan inovatif dalam menyikapi pengetahuan.

Minat dan kebiasaan membaca mempunyai hubungan timbal balik yang sangat erat. Seseorang yang memiliki minat dan perhatian yang tinggi terhadap bacaan tertentu akan selalu meluangkan waktunya untuk membaca, sehingga lama kelamaan akan terbiasa dengan kegiatan tersebut dan pada akhirnya memperoleh pemahaman yang lebih baik dibandingkan dengan orang yang tidak mempunyai minat dan kebiasaan membaca. Oleh karena itu, minat dan kebiasaan membaca harus terjalin dengan erat karena keduanya saling menentukan terbentuk tidaknya hal tersebut (Nurhayatin, 1997).

Sebagai lingkungan akademik, pengembangan minat dan kebiasaan membaca di sekolah hendaknya menjadi dasar untuk pengembangan intelektual. Benwari \& Nemine (2014) menyatakan bahwa guru dan semua stake holder yang terlibat dalam proses pembelajaran hendaknya tidak hanya sekedar menjadikan siswa sebagai objek untuk menjalankan perangkat pembelajaran yang mereka ciptakan. Lebih dari itu, guru di sekolah harus mampu menyadarkan dengan memberikan motivasi dan memberi contoh siswa agar selalu membina dan meningkatkan kualitas diri melalui kegiatan membaca buku-buku terutama yang berkaitan dengan bidang studi. Dukungan sarana dan fasilitas agar siswa merasa termotivasi dan nyaman juga sangat diperlukan untuk menumbuhkembangkan minat dan kebiasaan membacanya. Misalnya dengan ketersediaan bahan bacaan yang memadai, lingkungan tempat membaca yang kondusif dan representatif serta sarana pendukung lainnya.

Penelitian sebelumnya yang dilakukan Wahyuningtyas (2012) pada jenjang pendidikan tinggi membuktikan bahwa minat dan kebiasaan membaca memiliki hubungan yang positif dengan prestasi belajar. Artinya terdapat pengaruh antara kesuksesan seorang siswa dengan tinggi rendahnya minat dan kebiasaan membacanya. Penelitian tersebut juga memaparkan bahwa sebagian besar siswa masih memiliki minat dan kebiasaan membaca yang rendah. Oleh sebab itu sangat perlu dikembangkannya minat dan kebiasaan membaca sejak dini, terutama di lingkungan akademis seperti sekolah.

Pengembangan minat dan kebiasaan membaca siswa di lingkungan Sekolah Menengah Atas (SMA) selayaknya sudah mengalami perubahan, baik dari siswa maupun pengajarannya. Seperti yang dinyatakan oleh Brodjonegoro (2002) bahwa perubahan ditujukan pada pengajaran menjadi pembelajaran, peserta didik pasif menjadi pembelajar aktif, berpusat pada kemampuan (faculty) ke berpusat pada pembelajar, pembelajaran solitari (solitary learning) ke pembelajaran interaktif dan koperatif, pembelajaran di kelas menjadi pembelajaran di masyarakat. Pendapat tersebut secara gamblang mengatakan bahwa agar siswa memiliki minat dan kebiasaan membaca yang baik maka diperlukan suatu perubahan pada pembelajaran yang dilakukan. Perubahan yang dimaksud yaitu pada model pembelajaran yang dilandasi oleh prinsip-prinsip pembelajaran modern, seperti pembelajaran koperatif (cooperative learning), pembelajaran siswa aktif (student active learning), dan pembelajaran yang berpusat pada siswa 
(student-centered learning). Oleh sebab itu peran ganda seorang guru sangat dibutuhkan untuk mengatur sekaligus memotivasi siswa dalam pembelajaran.

\section{KESIMPULAN DAN SARAN}

\section{Kesimpulan}

Minat dan kebiasaan membaca siswa terhadap bahan bacaan yang berkaitan dengan pelajaran berpengaruh terhadap hasil belajar. Kesuksesan yang mereka capai untuk memperolah nilai maksimal dalam pembelajaran tergantung tinggi rendahnya minat dan kebiasaan membaca. Terlebih pada mata pelajaran geografi SMA yang banyak mengandung fakta, konsep, dan generalisasi sehingga sangat mutlak memerlukan aktifitas membaca untuk memahaminya. Salah satu upaya untuk mengembangkan minat dan kebiasaan membaca tersebut yaitu guru di sekolah harus mampu memberikan motivasi dengan cara memberikan contoh dan teladan kepada siswa agar selalu membina dan meningkatkan kualitas diri melalui membaca buku-buku terutama yang berkaitan dengan bidang studi. Selain itu dukungan sarana dan fasilitas agar siswa merasa termotivasi dan nyaman juga sangat diperlukan untuk menumbuhkembangkan minat dan kebiasaan membacanya.

\section{Saran}

Pada pembelajaran geografi di Sekolah Menengah Atas (SMA) hendaknya guru memberikan tugas-tugas yang berkaitan dengan aktivitas pengembangan membaca. Tugas tersebut diantaranya dapat berupa wajib menyelesaikan bahan bacaan tertentu dalam kurun waktu yang ditentukan dan juga disertai tugas berbasis proyek yang berkaitan dengan tema bahan bacaan tersebut. Diharapkan dengan tugas tersebut akan dapat memacu minat dan kebiasaan mmbaca siswa serta menumbuhkan daya nalar kritis mereka terhadap suatu bahan bacaan.

Di sisi lain untuk para pemangku kebijakan (pemerintah), sekolah, dan guru diharapkan tidak hanya memperhatikan pendidikan sebagai proyek komersial. Artinya hanya sekedar untuk memiliki buku saja terkadang tidak semua kalangan siswa dengan mudah akan dapat menikmatinya. Oleh karena itu perlu dukungan untuk penyediaan bahan bacaan yang berkualitas pada siswa yang kurang mampu. Misalnya pengadaan beasiswa khusus pengembangan minat baca, pengadaan ruang baca yang representatif dan layak pakai, pengadaan buku gratis untuk siswa dsb.

\section{DAFTAR RUJUKAN}

Astina, I.K. 2005. Pengantar Filsafat Geografi. Malang: FMIPA UM.

Bashir, I. dan Mattoo, N.H. 2012. A Study on Study Habits and Academic Prformance Among Adolescents (14-19). Years. International Journal of Social Science Tomorrow. 1(5): 1-5.

Benwari, Nnenna Ngozi \& Nemine, Ebi BB. 2014. Intensive Reading As a Study Habit and Students' Academic Achievement in Economics in Selected Secondary Schools in Bayelsa State, Nigeria. Journal of Curriculum and Teaching, (Online), 3 (2): 94-99, (www.sciedu.ca/jct), diakses 22 Maret 2016.

Bhan, K.S., dan Gupta, R. 2010. Study Habits and Academic 
Achievement Among the Students Belonging to Scheduled Caste and Non Scheduled caste Group. Journal of Applied Research in Education. 15(1): 1-9.

Brodjonegoro, S.S. 2002. Perguruan Tinggi Sebagai Kekuatan Moral. Disampaikan dalam Rapat Kerja Nasional Pimpinan Perguruan Tinggi Negeri Seluruh Indonesia, Yogyakarta.

Gie, The Liang. 1998. Cara Belajar Yang Efisien. Yogyakarta: Pusat Kemajuan Study.

Ginting, V. 2005. Penguatan Membaca, Fasilitas Lingkungan Sekolah dan Keterampilan Dasar Membaca Bahasa Indonesia serta Minat baca Murid. Jurnal Pendidikan Penabur. 4 (4): 17-35.

Listariono. 2009. Peranan Perpustakaan Sekolah dalam Upaya Menumbuhkan Minat Baca Siswa. UPT Perpustakaan. Materi disajikan dalam diklat pengelolaan perpustakaan bagi guru dan pustakawan di desa Landungsari kecamatan Dau kabupaten Malang tanggal 19 Desember 2009.

Nurhayatin. 1997. Minat Baca dan Kebiasaan Membaca di Masyarakat Perguruan Tinggi Aksentuasi Perpustakaan dan Pustakawan. Jakarta: IPI DKI.

Ogbodo, R. O. 2010. Effective study Habits in Educational Sector:
Counseling Implication. Edo Journal of Counseling. 3(2): 229239.

Owusu-Acheaw, M. \& Larson, Agatha G. 2014. Reading Habits Among Students and its Efect on Academic Performance: A Study of Students of Koforidua Polytechnic. Library Philosophy and Practice (ejournal). Paper 1130. (Online), (http://digitalcommons.unl.edu/cgi/ viewcontent.cgi? article $=2908 \&$ con text=libphilprac), diakses 22 Maret 2016.

Rahim, F. 2008. Pengajaran Membaca di Sekolah Dasar. Jakarta: Bumi Aksara.

Singh, Y. G. 2011. Academic Achievement and Study Habits Of Higher Secondary Students. International Referred Research Journal. 3(27): 2.

Wahyuningtyas, Neni. 2012. Hubungan Minat dan Kebiasaan Membaca dengan Prestasi Belajar Mahasiswa Pendidikan Geografi Universitas Negeri Malang. Tesis tidak diterbitkan. Malang: Jurusan Pendidikan Geografi Program Pasca Sarjana Universitas Negeri Malang.

Wigfield, A, \& Guthrie, J. T. 1997. Motivation for Reading: Individual, Home, Textual, and Classroom Perspective. Educational Psychologist. Vol. 32.No.57. 